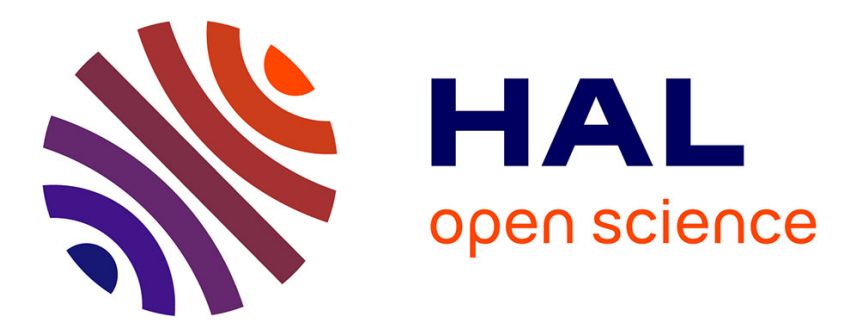

\title{
Seasonality and season of birth of modern and late Neolithic sheep from South-Eastern France using tooth enamel $\delta 180$ analysis
}

\author{
Emilie Blaise, Marie Balasse
}

\section{> To cite this version:}

Emilie Blaise, Marie Balasse. Seasonality and season of birth of modern and late Neolithic sheep from South-Eastern France using tooth enamel $\delta 18 \mathrm{O}$ analysis. Journal of Archaeological Science, 2011, 38, pp.3085-3093. 10.1016/j.jas.2011.07.007 . hal-00755225

\section{HAL Id: hal-00755225 \\ https://hal.science/hal-00755225}

Submitted on 20 Nov 2012

HAL is a multi-disciplinary open access archive for the deposit and dissemination of scientific research documents, whether they are published or not. The documents may come from teaching and research institutions in France or abroad, or from public or private research centers.
L'archive ouverte pluridisciplinaire HAL, est destinée au dépôt et à la diffusion de documents scientifiques de niveau recherche, publiés ou non, émanant des établissements d'enseignement et de recherche français ou étrangers, des laboratoires publics ou privés. 
Accepted manuscript published in Journal of Archaeological Science 38 (2011) 3085-3093 ***

http://dx.doi.org.gate3.inist.fr/10.1016/j.jas.2011.07.007

\title{
SEASONALITY AND SEASON OF BIRTH OF MODERN AND LATE NEOLITHIC SHEEP FROM SOUTH-EASTERN FRANCE USING TOOTH ENAMEL $\delta^{18} O$ ANALYSIS
}

\author{
Emilie Blaise $^{1}$ and Marie Balasse ${ }^{1}$ \\ 1: UMR 7209 CNRS - USM 303 MNHN Paris « Archéozoologie, Archéobotanique : Sociétés, Pratiques et \\ Environnements » \\ e.blaise@mnhn.fr and balasse@mnhn.fr
}

Keywords: SHEEP, SEASONNALITY AND SEASON OF BIRTH, SOUTH-EASTERN FRANCE, OXYGEN

STABLE ISOTOPE RATIO, TOOTH ENAMEL, LATE NEOLITHIC, COLLET-REDON.

\begin{abstract}
Stable oxygen isotopic analysis of tooth enamel was used to investigate seasonality and season of birth in sheep. Analyses were performed on the teeth of eight modern sheep bred at the Carmejane farm in south-eastern France and born in different periods of the year. This reference data set confirms that oxygen isotopic records in the second and third molars can be used to differentiate between sheep born in late winter and those born in early autumn. The results show that inter-individual variability in the timing of tooth formation is low for the second lower molar and more pronounced for the third lower molar in this population. The duration of the process of enamel mineralization has been estimated at approximately six months. The teeth of four sheep and two goats from the late Neolithic site of ColletRedon in south-eastern France were analysed using the same methodology. At this site, lambing occurred between the late winter and early spring. A slight difference appears in the seasonal sequence recorded in sheep and goat, although it cannot be determined, whether this is due to different timing of tooth development, or an actual shift in the birth period. From the distribution of slaughter ages ands birth period, it is suggested that domestic caprines were killed throughout the year and that ColletRedon was probably a permanent settlement.
\end{abstract}

\section{INTRODUCTION}

Birth season is a central parameter of pastoral economies, determining the rhythm of breeding activities and the availability of animal resources, including milk. However, birth pattern might have changed according to husbandry practices and environmental conditions. Determining the seasonality and season of births of Neolithic caprines using $\delta^{18} \mathrm{O}$ analysis serves to refine the interpretation of mortality patterns in terms of seasonality of slaughter and consequently helps to define the strategies of Neolithic herders and the timing of farming practices, while providing key elements to the seasonality of site occupation (Balasse et al. 2003; Blaise 2010).

The analysis of the stable oxygen isotopic composition $\left(\delta^{18} \mathrm{O}\right)$ of tooth enamel, following the methodology of sequential sampling, has already been successfully applied to modern and archaeological populations to determine the seasonality of birth in horses, sheep, goats and cattle (Balasse et al. 2002, 2003, 2009; Balasse and Tresset 2007; Bryant et al. 1996a, 1996b, 1996c; Fricke and O'Neil 1996; Henton 2010). The $\delta^{18} \mathrm{O}$ of skeleton bioapatite is linked to the $\delta^{18} \mathrm{O}$ of drinking water and plant water ingested by animals, indirectly to meteoric water (Iacumin and Longinelli 2002; Longinelli 1984; Luz et al. 1984). At high and middle latitudes, the $\delta^{18} \mathrm{O}$ of precipitation varies seasonally with ambient temperature (Dansgaard 1964; Gat 1980). During tooth growth, enamel bioapatite records and preserves seasonal changes. Because within a species, the timing of tooth growth is fixed, individuals born in the same period of the year record the same seasonal sequence in the same portion of the tooth. Inversely, individuals born in different seasons have these sequences 
shifted (Balasse et al. 2003; Fricke and O'Neil 1996). Due to uncertainties in the timing and duration of tooth mineralization, modern reference sets are required before the season of birth can be inferred from archaeological assemblages using this methodology. For sheep, one reference data set exists on a modern population from the Orkney archipelago born in the spring (Balasse et al. 2005, 2009; Balasse and Tresset 2007).

In the present study, results are presented from a new reference data set of sheep teeth collected on a farm in south-eastern France, including individuals born in winter and late summer to early autumn (Blaise 2006, 2010). The objectives are to explore the variability in the development of tooth growth, to investigate the duration of mineralization of tooth enamel in the second and third molars, and to confirm the distinction in the oxygen isotopic record of sheep born in different periods of the year. This new data set is then used to estimate the season of birth of archaeological specimens from the late Neolithic site of Collet-Redon (Martigues, Bouches-du-Rhône, France).

\section{MATERIAL AND METHODS}

\section{The modern reference set}

The study was performed on the teeth from eight domestic ewes (Ovis aries) from the primitive "southern pre-Alps" breed, raised on an experimental farm (Carmejane farm, Alpes-de-HauteProvence, France) and born in late winter and late summer (Tabl.1). These are culled females slaughtered in May 2004. The farmstead is located near Digne (Fig.1), in the pre-Alpine region characterized by strong climatic constraints including summer drought, erratic rains and snow in winter. Until 2004, the herd was managed on a yearly basis on the rangelands nearby, without any movement of the flocks in summer pastures (Blaise 2006, 2010). The 520 sheep are managed in two batches balanced according to the lambing season. In the barn, the animals are provided with water from the city (source capture of the town). Outdoors, the available water came half from the city and half from a local well (groundwater source) until year 2000. Since that date, water comes essentially from the local well. That may result in some attenuation of seasonal variations in drinking water $\delta^{18} \mathrm{O}$ (outdoors only) of "Ovis 1216" and "Ovis 1511" born in 2001 compared to all other sheep, born in year 2000 or earlier (Tabl. 1). The third molar from eight sheep and the second molar from six of them were selected for stable carbon and oxygen isotope analysis (Blaise 2010). Four second molars were sampled and analysed in 2006 and two additional in 2010, in order to increase this data set. A total of 214 enamel samples were analysed.

\section{The archaeological specimens}

Archaeological molars were extracted from mandibles from the assemblage of Collet-Redon in southeastern France (Martigues, Bouches-du-Rhône, France) (Fig.1). Dental remains come from the occupation levels attributed to the Late Neolithic Couronnien (late $4^{\text {th }}-$ mid $3^{\text {rd }}$ mil. BC), located in the

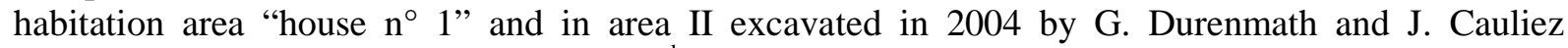
(Durenmath et al. 2007). During the $3^{\text {rd }}$ mil. BC, in this temperate zone of Western Europe, Mediterranean climate appears gradually, characterized by mild winters and dry summers, but the climate was nevertheless wetter than today (Berger 1996; Magny et al. 2002; Magny 2004, 2010; Martin 2004). At Collet-Redon, the Late Neolithic occupation has delivered many witnesses of agropastoral activities and paleo-environmental data show a high human impact on local landscape (Cauliez et al. 2006). In this site, livestock rearing was supplemented by fishing and gathering (Blaise 2010; Durrenmath et al. 2007). The herds were composed mainly of sheep, goats and cattle, exploited for their meat and milk. Pigs were rare and provided a complement of meat and fat. The high frequencies of cattle aged over 9 years and the occurrence of bone pathologies indicate the use of this animal for work (Blaise 2010). Six lower second molars (M2) were selected from well-preserved and complete dental rows belonging to adults aged between 2 and 6 years, including four attributed to sheep (Ovis aries) and two to goats (Capra hircus). The distinction between both species was performed according to morphological criteria (Balasse and Ambrose 2005; Helmer 2000; Halstead et al. 2002; Payne 1985). They yielded a total of 82 enamel samples. 


\section{Methods}

Sequential sampling was performed in order to reconstruct the isotopic history of the individual over the time of tooth development (Balasse 2002, 2003; Balasse et al. 2002, 2003; Fricke \& O’Neil 1996; Kohn et al. 1998; Sharp \& Cerling 1998). Tooth surfaces were cleaned by abrasion. A series of enamel samples was removed by drilling with a diamond bit from the tooth surface, and from the apex to the crown root junction. The sampling spans the width of a lobe. The second molars were sampled on the posterior lobe, the third molars on the middle lobe. Each sampling is located by its distance from the enamel-root junction (thereafter referred to as ERJ).

The collected enamel powder was treated for bioapatite extraction according to the protocol described in Balasse et al. (2002). Each enamel sample (5 to $7 \mathrm{mg}$ ) reacted with sodium hypochlorite 2-3\% (24h, $0.1 \mathrm{ml} / \mathrm{mg}$ ) to remove organic matter and was then treated with $0.1 \mathrm{M}$ acetic acid (4h, $0.1 \mathrm{ml} / \mathrm{mg})$ to remove exogenous carbonates. This protocol is usually recommended for archaeological samples to eliminate contamination from exogenous carbonates. Because it was shown to induce a shift in $\delta^{18} \mathrm{O}$ values (Koch et al. 1997), it was also applied to the modern samples in order to ensure that both sets went through the same analytical procedure. A small amount of bioapatite (600 $\mu \mathrm{g}$ approximately) was placed into individual vessels to react under vacuum with phosphoric acid at $70^{\circ} \mathrm{C}$ in a Kiel carbonate IV. The cryogenically purified $\mathrm{CO}_{2}$ was analysed in a Delta V Advantage mass spectrometer.

Over the period of analysis of the bioapatite samples in 2006, analytical precision, determined by 133 analyses of the laboratory internal carbonate standard (Marbre LM), is $0.09 \%$ o for $\delta^{18} \mathrm{O}$. Over the same period, 45 analyses of the international standard NBS 19 produce an analytical precision of $0.08 \%$. In 2010, analytical precision is $0.06 \%$ for $\delta^{18} \mathrm{O}$, defined by 16 analyses of Marbre LM.

To assess the season of birth, the record of the isotopic variation and its location in the crown height were compared between the modern and archaeological sheep. However, due to possible differences in tooth morphology including full tooth height between modern and Neolithic sheep, direct comparisons might induce a bias. For this reason, all distances from the enamel root junction were normalized using the mean transverse diameter of modern sheep (measuring protocol after Ducos 1968). For all archaeological caprines, distances from ERJ were divided by the individual transverse diameter and multiplied by the mean transverse diameter of modern sheep $(8.1 \mathrm{~mm})$.

\section{RESULTS}

\section{Stable oxygen isotope ratios in enamel bioapatite}

Results from the isotope analysis of enamel bioapatite from modern and archaeological specimens are presented in Appendix I. Position in tooth crown of the lowest and highest $\delta^{18} \mathrm{O}$ values measured on each second and third molar of the modern sheep are reported in Table 1 and in Table 2 for the domestic caprines from Collet-Redon. Whole sequences are shown in Figures 2, 3 and 4.

The $\delta^{18} \mathrm{O}$ values measured in the modern "southern pre-Alps" ewes vary between -6.9 \%o and $-0.5 \%$ in the M2 and between $-7.2 \%$ and $-0.2 \%$ in the M3. The $\delta^{18} \mathrm{O}$ values measured in the M2 of the archaeological specimens vary between $-2.1 \%$ and $1.8 \%$. For all these individuals, the pattern of intra-tooth variation of $\delta^{18} \mathrm{O}$ values is sinusoidal, most probably reflecting the seasonal changes in water $\delta^{18} \mathrm{O}$. The amplitude of variation is close to $4 \%$ to $6 \%$ for the modern ewes (3.9\% to $6.3 \%$ in the M2; $3.5 \%$ to $5.4 \%$ in the M3; Table 1) and varies from $2.1 \%$ to $3.6 \%$ for the sheep and goats from Collet-Redon (Table 2). A shorter amplitude of variation in the archaeological sheep compared to the modern individuals may be due to local climatic conditions: Collet-Redon is located nearby the Mediterranean coast whereas the Carmejane farm is settled further inland in the pre-alpine zone where the annual amplitude of temperature is higher.

\section{Inter-group variability in the $\delta^{18} \mathrm{O}$ values of modern sheep}

In the second and third molars for all modern sheep, an inter-individual variability can be observed in the $\delta^{18} \mathrm{O}$ values, related most probably mainly to inter-annual variations in ambient temperature. The inter-individual variability observed in the localisation of the time sequence in tooth height shows 
clear separation of two groups, depending on whether the individuals were born in late winter or in autumn (Figures 2 and 3).

In the second molars (Fig. 2), in sheep born between late January and early February, the maxima $\delta^{18} \mathrm{O}$ are recorded in the crown of the M2 between $4 \mathrm{~mm}$ and $8 \mathrm{~mm}$ from the ERJ and the minima between 16 and $21 \mathrm{~mm}$. In the winter group, the sequence recorded during growth in the second portion of the crown of the M2 is winter / spring / summer (the beginning of the recording is truncated by tooth wear): the maxima are recorded between $3 \mathrm{~mm}$ and the ERJ in Ovis 0026 and at around $6 \mathrm{~mm}$ in Ovis 1216, and the minima in the middle of the crown (16-19 mm from the ERJ). In sheep born in late September, the maxima are recorded in the crown between $17 \mathrm{~mm}$ and $22 \mathrm{~mm}$ from the ERJ and the minima between 8 and $10 \mathrm{~mm}$ in Ovis 9470, Ovis 0522 and Ovis 0562, but at around $2 \mathrm{~mm}$ in Ovis 1511. In Ovis 9470, the isotopic record is partly truncated in the upper part of the molar because of tooth wear. In the autumn group, the sequence recorded during M2 formation is late summer / autumn / winter / spring.

In the third molars (Fig.3), in sheep born from late January to early February, the highest $\delta^{18} \mathrm{O}$ values are recorded between $20 \mathrm{~mm}$ and $35 \mathrm{~mm}$ from the ERJ and the lowest $\delta^{18} \mathrm{O}$ values between 7 and 20 $\mathrm{mm}$. In Ovis 8143, the isotopic record is partly truncated in the upper part of the molar because of tooth wear. Ovis 9726, born in the spring (April 29), has recorded $\delta^{18} \mathrm{O}$ maxima between 20 and 25 $\mathrm{mm}$ and $\delta^{18} \mathrm{O}$ minima between 4 and $9 \mathrm{~mm}$. In individuals born in September, the highest $\delta^{18} \mathrm{O}$ values are recorded between 12 and $20 \mathrm{~mm}$ from the ERJ. Ovis 0562 recorded the lowest $\delta^{18} \mathrm{O}$ values at around $7 \mathrm{~mm}$. The minimum $\delta^{18} \mathrm{O}$ value is not attained in the three other individuals and therefore it cannot be located with certitude (Ovis 9470, Ovis 1511, Ovis 0522).

In the third molars, the sequence of the seasonal cycle recorded is well offset between individuals born in winter and those born in the autumn. For example, Ovis 1511 (born in September) records, in the last thirty millimeters of the tooth, spring-summer-autumn, while Ovis 0026 (born in February) records the sequence summer-autumn-winter. However, within each group of sheep born in the same time of the year, inter-individual variability can be important, partially reducing the applicability of this M3 reference data set as long as it is used to specify precisely the season of birth. A higher interindividual variability in the record of $\delta^{18} \mathrm{O}$ sequences in the M3 should be kept in mind when interpreting such sequences from archaeological specimens.

\section{Inter-individual variations in the $\delta^{18} \mathrm{O}$ values of the Neolithic caprines from Collet-Redon}

At Collet-Redon, in sheep and goat, inter-individual differences are observed in the range of variations of $\delta^{18} \mathrm{O}$ values during M2 formation, possibly related to inter-annual variations in temperature. In sheep, the lowest $\delta^{18} \mathrm{O}$ values are recorded in the crown of M2 around 16-22 mm from the ERJ and the highest between 5 and $10 \mathrm{~mm}$ from the ERJ (Fig.4). In goats, $\delta^{18} \mathrm{O}$ minima are attained in the crown of M2 around 21-25 mm and the maximum between 10 and $15 \mathrm{~mm}$ (Fig.4).

\section{DISCUSSION}

\section{Duration of the process of enamel mineralization}

According to radiographic data on the duration of tooth formation of 106 Awassi sheep (Weinreb and Sharav 1964) and 48 "southern pre-Alps" (Milhaud and Nezit 1991), the crown of the M2 begins formation during the second month and is completed at 12 month. In Carmejane ewes born in JanuaryFebruary (Ovis 1216 and Ovis 0026), winter values would be expected in the part of the crown formed last (Fig.2). However, in this part of the crown, the measured $\delta^{18} \mathrm{O}$ values are the highest, corresponding to summertime. Similarly, for individuals born in September (Ovis 0522, Ovis 0562 and Ovis 9470), the $\delta^{18} \mathrm{O}$ values measured in the part of the crown formed last correspond to a late spring / early summer signal rather than autumn. The pattern of intra-tooth variation of $\delta^{18} \mathrm{O}$ values of Ovis 1511 is slightly offset from the others because it was born a little earlier and possibly also because of a difference in the timing of tooth development.

Histological investigations on growing teeth in sheep and goats (Suga 1982) have demonstrated that the enamel mineralization is a progressive and discontinuous process. This intra-tooth isotopic study 
of modern sheep molars shows that a gap appears between the isotopic record and the chronology of tooth development in "southern pre-Alps" ewes from Carmejane. The shift between the expected and measured signal might correspond to the time required for mineralization, around half a seasonal cycle (approximately 6 months). This estimation is similar to that observed in other sheep (Zazzo et al. 2010).

\section{Inter-individual variability in the timing of tooth growth in the Carmejane sheep population}

Inter-individual variability in the M2 formation appears to be small in the Carmejane sheep population (Fig.2). In individuals born in the same period of the year, the highest $\delta^{18} \mathrm{O}$ values, on the one hand, and the lowest, on the other hand, are recorded in the crown within only a few millimetres. This slight offset (the localisation of the maxima is distributed over $4.6 \mathrm{~mm}$ for autumn group and $2.5 \mathrm{~mm}$ for winter group) may be due partly to a slight inter-individual variation in the timing of tooth growth and/or enamel mineralization. Inter-individual variability seems to be more pronounced for the M3 than for the M2 in this modern breed. No significant difference has been detected in the tooth wear and eruption stage between third molars of individuals of the same age (Blaise 2006, 2010). However, some variations appear in the timing of the isotopic signal with tooth development between individuals born in the same season (Fig.3).

In the M3, for sheep born between late January and early February, the localisation of the highest $\delta^{18} \mathrm{O}$ values is over $10 \mathrm{~mm}$ (22.5 mm to $32.5 \mathrm{~mm}$ from ERJ). For sheep born in September, the highest $\delta^{18} \mathrm{O}$ values are recorded between $12.5 \mathrm{~mm}$ and $21 \mathrm{~mm}$, over $8.5 \mathrm{~mm}$.

When comparing isotopic sequences after normalizing distance from ERJ, the shift between individuals does not disappear for M3 because of very little difference in tooth morphology of the Carmejane sheep population (data not shown).

\section{Assessing seasonality and season of birth of sheep and goats from Collet-Redon}

At Collet-Redon, results suggest that these domestic caprines were born in the same period of the year. However, some variability appears in the timing of the isotopic record between sheep and goats (Fig.4). The lambing season for the late Neolithic sheep and goats can be estimated by comparison with the modern reference data set. In four archaeological sheep, the variation in $\delta^{18} \mathrm{O}$ values along tooth crown seems to fit with that of modern specimens born in winter (Fig.5). The pattern of $\delta^{18} \mathrm{O}$ intra-tooth variation of goats is slightly shifted with those of modern individuals and archaeological sheep. If this shift does not reflect a difference in the timing of tooth development between both species, this could indicate a slight shift in the birth season: goats would be born slightly later in the year (Fig.5). However, the limited number of archaeological individuals included in the study precludes any firm conclusion on this point.

These results thus reveal a marked seasonality of births on the site (one single birth peak identified from these six specimens). Aside from the inter-individual and interbreed variability in the process of tooth development and mineralization, we may thus conclude that the birth season of sheep from Collet-Redon is similar to that of modern sheep born in January-February.

\section{Birth distribution, husbandry practices and hypothesis of period occupation of Collet-Redon}

At Collet-Redon, lambing was grouped in late winter. This birth season is earlier than for wild caprines (Alpine ibex and chamois) living currently in this geographic area in France, in which births were from spring to early summer with a peak in April, and in European mouflon (middle to late April) (Garel et al. 2005; Huet 2002; Pfeffer 1967). The lambing period estimated at Collet-Redon is similar to that observed presently in traditional breeding in the Mediterranean area (Blaise 2006, 2010; Halstead 2005; Helmer et al. 2005). This shift might be considered as a consequence of domestication (Lincoln et al. 1990; Thiéry et al. 2002). This does not necessarily require deliberate intervention from the herder at this very site, but could also reflect a general shift towards earlier births in domestic herds possible induced by diet management and protection against weather conditions.

From the season and distribution of births, assumptions can be made about the yearly availability of milk. At Collet-Redon, sheep were exploited for meat and milk (Blaise 2010). The kill-off pattern (N 
= 65 teeth; NMI = 56), reveals that most individuals were killed between 2 months and 2 years $(64 \%)$ with a peak at 2-6 months (30\%), providing tender meat and a good meat productivity, while allowing control of herd demography. Almost $34 \%$ of adults were slaughtered between 2 and 6 years suggesting that a number of females were kept for milk exploitation. Considering that the ewe may be able to produce milk for approximately five months, according to data from female European mouflon and primitive sheep breeds in this region (Pfeffer 1967; Quittet 1976; Toussaint 2001), late winter birth would initiate milk production until early summer (Fig.6).

Our study also has implications for the investigation of the timing of site occupation. From the season of lambing and the mortality profile, it is possible to deduce when the animals were slaughtered in the year. This requires a very precise determination of the age of mortality. As most domestic caprines were slaughtered before two years, the ages were estimated from the deciduous lower fourth premolars using wear stages and preserved crown height (Gourichon 2004). The error in the age determination is within 1.5 months. At Collet-Redon, from the measurement of eight premolars, six caprines died between 6 and 9 months $(\mathrm{N}=6)$, and two others respectively at 11-12 months and 17-18 months. A goat died to 2 months from the premolar wear. Animals were slaughtered almost every month of the year, only May-June and December are not represented (Fig.6). According to the seasonality of slaughter (pluri seasonal distribution), we can consider that this occupation was very probably permanent.

\section{CONCLUSION}

The analysis conducted on the modern reference sheep from Carmejane confirms that sequential $\delta^{18} \mathrm{O}$ analysis in tooth enamel allows distinction between sheep born in different periods of the year. The profile of the variation of oxygen isotope ratios along the tooth of ewes born in winter differs markedly from that of sheep born in the autumn.

For winter births (late January- early February), individuals have recorded maxima at around $6 \mathrm{~mm}$ from ERJ in their second molar and minima at around $18 \mathrm{~mm}$. Whereas for early autumn births (September), maxima are about $20 \mathrm{~mm}$ and minima $8 \mathrm{~mm}$ from the enamel-root junction (on average). Seasonal sequences recorded during the M2 development are clearly opposed between both birth groups. Regarding third molars, for sheep born in late winter, the highest $\delta^{18} \mathrm{O}$ values are measured at $25 \mathrm{~mm}$ from ERJ on average and the lowest $\delta^{18} \mathrm{O}$ values at around $12 \mathrm{~mm}$ on average. For September births, maxima are recorded at around $16 \mathrm{~mm}$ from ERJ and minima at $5 \mathrm{~mm}$. Some variability also appears in the timing of growth tooth of the ewes from Carmejane, especially for their third molar. "Southern pre-Alps" ewes are from an improved breed. Analysis of third molars of more primitive sheep breed, such as North Ronaldsay sheep raised in the northern islands of Orkney (Scotland), showed that this variability is not always as high (Balasse and Tresset 2007).

The pattern of intra-tooth isotopic variation of the second molars suggests that completion of enamel mineralization may have required approximately six months. The confirmation of a long duration in enamel mineralization, inducing a shift between the timing of tooth formation and the isotopic record in tooth enamel, shows that these experiments and data on modern sheep are essential for interpreting intra-tooth variations in isotope ratio from archaeological specimens. Using this isotopic dataset of modern sheep, we have been able to estimate distribution and period of births of Neolithic sheep in Collet-Redon and to deduce the rhythm of human activities at this Late Neolithic site. At this site, births were grouped between the late winter and the early spring.

The reference $\delta^{18} \mathrm{O}$ data set on modern sheep presented in this study is the first step of a wider research axis whose main objective is to investigate the rhythm of pastoral tasks in the late Neolithic of southeastern France. The assemblage from Collet-Redon was first used to test the applicability of the protocol to archaeological specimens. The results obtained at Collet-Redon about birth seasonality and birth season of sheep and goat illustrate a husbandry system that may be adapted to the local environmental settings - the site is situated nearby the present coast. Additional data were gathered from the sub-contemporaneous site of La Citadelle (Blaise 2010) and will be from other late Neolithic sites including La Fare and La Brémonde, located in the same geographic zone as Collet-Redon but further inland (Fig.1). These future applications will contribute to a better understanding of breeding practices, site occupation, settlement pattern, land management and socio-economic organization of societies during the $3^{\text {rd }}$ mil. BC in the Mediterranean area. 


\section{ACKNOWLEDGEMENTS}

This study was performed in the framework of a CNRS/INSU Eclipse II project "Climate constraints and development of Neolithic farming in Western Europe the transition to Atlantic / Sub-Boreal" (dir. A. Tresset and M. Balasse, CNRS, UMR 7209) and Emilie Blaise's doctorat (UMR 6636, Aix-enProvence) under the direction of R. Chenorkian and D. Helmer. The doctoral fellowship for Emilie Blaise was financed by the Association pour le Développement de l'Enseignement et des Recherches of Provence-Alpes-Côte d'Azur and the Musée de Préhistoire des Gorges du Verdon (Quinson, Alpesde-Haute-Provence, dir. J. Gagnepain). Emilie Blaise has special thoughts for J. Gagnepain, who died during the writing of this article. She sincerely thanks him for his warm welcome and his assistance. Support for this research was also provided by the European Research Council for a post-doctoral fellowship for Emilie Blaise and stable isotope analyses (Starting Grant $\mathrm{n}^{\circ} 202881$ SIANHE, dir. M. Balasse). The isotope analyses were performed at the IRMS service of the MNHN (SSMIM) with technical assistance of Joël Ughetto. We would like to thank the people who provided the modern sheep mandibles and information on "Southern pre-Alps" ewes and on herding practices: the team of the Carmejane experimental farm, particularly its director François Demarquet, various veterinary services, those from the Sisteron slaughterhouse, who enabled the recovery of the mandibles without losing traceability, and Robin Furestier (UMR 5140 Lattes) for helping with the cutting.

\section{REFERENCES}

Balasse, M., 2002. Reconstructing dietary and environmental history from enamel isotopic analysis: time resolution of intra-tooth sequential sampling, International Journal of Osteoarchaeology, 12, 155-165.

Balasse, M., 2003. Potential biases in sampling design and interpretation of intra-tooth isotope analysis, International Journal of Osteoarchaeology, 13, 3-10.

Balasse, M., Ambrose S. H., 2005. Distinguishing sheep and goats using dental morphology and stable isotopes $\mathrm{C}_{4}$ grassland environments, Journal of Archaeological Science, 32, 691-702.

Balasse, M., Ambrose, S. H., Smith, T. D., Price, D., 2002. The seasonal mobility model for prehistoric herders in the south-western Cape of South Africa assessed by isotopic analysis of sheep tooth enamel, Journal of Archaeological Science, 29, 917-932.

Balasse, M., Mainland, I. and Richards, M. P., 2009. Stable isotope evidence for seasonal consumption of marine seaweed by modern and archaeological sheep in the Orkney archipelago (Scotland), Environmental Archaeology, 14, 1, 1-14.

Balasse, M., Smith, B., Ambrose, S. H., Leigh, S., 2003. Determining sheep birth seasonality by analysis of tooth enamel oxygen isotope ratios: the Late Stone Age site of Kasteelberg (South Africa), Journal of Archaeological Science, 30, 205-215.

Balasse, M., Tresset, A., 2007. Environmental constraints on the reproductive activity of domestic sheep and cattle: what latitude for the herder? Anthropozoologica, 42, 71-88.

Blaise, E., 2006. Référentiel actuel de brebis « Préalpes du sud » (Digne, Alpes-de-Haute-Provence, France): pratiques d'élevage et âges dentaires, Anthropozoologica, 41, 191-214.

Blaise, E., 2010. Economie animale et gestion des troupeaux au Néolithique final en Provence : approche archéozoologique et contribution des analyses isotopiques de l'émail dentaire, Oxford: John \& Erica Hedges Ltd., April 2010 (British Archaeological Reports, International Series 2080).

Berger, J.-F., 1996. Le cadre paléographique des occupations du Bassin Valdainais (Drôme) à l'Holocène, Thèse de Doctorat, Paris, Université Paris I Panthéon-Sorbonne. 
Bryant, J. D., Froelich, P. N., Showers, W. J., Genna, B. J., 1996a. A Tale of Two Quarries: biologic and taphonomic signatures in the oxygen isotope composition of tooth enamel phosphate from modern and Miocene equids, Palaios, 11, 397-408.

Bryant, J. D., Froelich, P. N., Showers, W. J., Genna, B. J., 1996b. Biologic and climatic signals in the oxygen isotopic composition of Eocene-Oligocene equid enamel phosphate, Palaeogeography, Palaeoclimatology, Palaeoecology, 126, 75-89.

Bryant, J. D., Koch, P. L., Froelich, P. N., Showers, W. J., Genna, B. J., 1996c. Oxygen isotope partitioning between phosphate and carbonate in mammalian apatite, Geochimica et Cosmochimica Acta, 60 (24), 5145-5148.

Cauliez, J., Blaise, E., Cade, C., Desse, J., Desse-Berset, N., Durrenmath, G., Gilabert, C., Martin, S., Vella, C., 2006. Paysages et implantations du Néolithique final à l'Âge du Bronze ancien au ColletRedon (Martigues, Bouches-du-Rhône), in Fouéré, P., Chevillot, C., Courtaud, P., Ferullo, O., Leroyer, C., (Eds.), Paysages et peuplements. Aspects culturels et chronologiques en France méridionale, Actes des Ges rencontres méridionales de Préhistoire récente, Périgueux, 14-16 octobre 2004, Préhistoire du Sud-Ouest, suppl. n 11, ADRAHP, Périgueux, Préhistoire du Sud-Ouest, pp.125139.

Dansgaard, W., 1964. Stable isotopes in precipitation, Tellus, XVI, 436-468.

Ducos, P., 1968. L'origine des animaux domestiques de Palestine, Bordeaux, Université de Bordeaux, XVI-194 p., 14 pl. (Mémoire de l’Institut de Préhistoire de l’Université de Bordeaux, 6).

Durrenmath, G., Cauliez J., Blaise, E., Cade, C., Desse, J., Desse-Berset, N., 2007. Le Collet-Redon (Martigues, Bouches-du-Rhône) : passé, présent et futur des recherches sur l'économie d'un site néolithique final, in Evin J. (Eds.), Un siècle de construction du discours scientifique en Préhistoire, Actes du XXVI ${ }^{e}$ Congrès Préhistorique de France, Avignon, 21-25 septembre 2004, Volume III, Paris, Société Préhistorique Française, pp. 387-399.

Fricke, H. C., O'Neil, J. R., 1996. Inter- and intra-tooth variation in the oxygen isotope composition of mammalian tooth enamel phosphate: implications for palaeoclimatological and palaeobiological research, Palaeogeography, Palaeoclimatology, Palaeoecology, 126, 91-99.

Gat, J. R., 1980. The isotopes of hydrogen and oxygen in precipitation, in Fritz, P., Fontes J.-C. (Eds.), Handbook of Environmental Isotope Geochemistry, Vol.1, The terrestrial Environment, Amsterdam, Elsevier, 21-42.

Garel, M., Cugnasse J.-M., Gaillard, J.-M., Loison, A., Gibert, P., Douvre, P., Dubray, D., 2005. Reproductive output of female mouflon (Ovis gmelini musimon x Ovis sp.): a comparative analysis, Journal of Zoology, 266, p. 65-71.

Gourichon, L., 2004. Faune et saisonnalité : l'organisation temporelle des activités de subsistance dans l'Epipaléolithique et le Néolithique précéramique du Levant Nord (Syrie). Thèse de doctorat, Lyon, Université Lumière - Lyon 2.

Halstead, P., Collins, P., Isaakidou, V., 2002. Sorting the sheep from the goats: morphological distinction between the mandibles and mandibular teeth of adult Ovis and Capra, Journal of Archaeological Science, 29, 545-553.

Halstead, P., 2005. Resettling the Neolithic: fauna evidence for seasons of consumption and residence at Neolithic sites in Greece, in Bailey, D., Whittle, A. and Cummings, V. (Eds), (Un)settling the Neolithic. Oxbow, Oxford, pp. 38-50. 
Helmer, D., 2000. Discrimination des genres Ovis et Capra, à l'aide des prémolaires inférieures 3 et 4 et interprétation des âges d'abattage : l'exemple de Dikili Tash (Grèce), Anthropozoologica, 31, 29-38.

Helmer, D., Gourichon, L., Sidi Maamar, H., Vigne, J.-D., 2005. L'élevage des caprinés néolithiques dans le sud-est de la France : saisonnalité des abattages, relations entre grottes-bergeries et sites de plein air, Anthropozoologica, 40, 167-189.

Henton, E. Meier-Augenstein W. and Kemp H. F., 2010. The use of oxygen isotopes in sheep moalrs to investigate past herding practices at the Neolithic settlement of Çatalhöyük, central Anatolia, Archaeometry, 52, 429-449.

Huet, P. 2002. Animaux sauvages de nos contrées. Les mammifères dans leur milieu. Edition Arthaud.

Iacumin, P., Longelli, A., 2002. Relationship between $\delta^{18} \mathrm{O}$ values for skeletal apatite from reindeer and foxes and yearly mean $\delta^{18} \mathrm{O}$ values of environmental water, Earth and Planetary Science Letters, 201, 213-219.

Koch, P.L., Tuross, N. and Fogel, M.L., 1997. The effects of sample treatment and diagenesis on the isotopic integrity of carbonate in biogenic hydroxylapatite, Journal of Archaeological Science, 24, 417-429.

Kohn, M., Schoeninger, M.J., Valley, J. W., 1998. Variability in oxygen isotope compositions of herbivore teeth: reflections of seasonality or developmental physiology? Chemical Geology, 152, 97112.

Lincoln, G.A, Lincoln C.E., McNeilly A.S.,1990. Seasonal cycles in the blood plasma concentration of FSH, inhibin and testosterone, and testicular size in rams of wild, feral and domesticated breeds of sheep. Journal of Reproduction and Fertility, 88, 623-633.

Longinelli, A., 1984. Oxygen isotopes in mammal bone phosphate: A new tool for paleohydrological and paleoclimatological research? Geochimica et Cosmochimica Acta, 48, 385-390.

Luz, B., Kolodny, Y., Horowitz, M., 1984. Fractionation of oxygen isotopes between mammalian bone-phosphate and environmental drinking water, Geochimica et Cosmochimica Acta, 48, 16891693.

Magny, M., 2004. Holocene climatic variability as reflected by mid-European lake-level fluctuations, and its probable impact on prehistoric human settlements, Quaternary International, 113, 65-80.

Magny, M., (2010). Eléments pour une histoire du climat en Europe occidentale de 4500 à 2500 BC, in Lemercier, O., Furestier, R., Blaise, E. (Eds), 4è Millénaire. La transition du Néolithique moyen au Néolithique final dans le sud-est de la France et les régions voisines, Lattes, Publications de l'UMR 5140 / ADAL (Monographies d'Archéologie Méditerranéenne, 27), pp. 9-15.

Magny, M., Miramont, C., Sivan, O., 2002. Assessment of the impact of climate and anthropogenic factors on Holocene Mediterranean vegetation in Europe on the basis of palaeohydrological records, Palaeogeography, Palaeoclimatology, Palaeoecology, 186, 47-59.

Martin, S., 2004. Caractérisation de l'anthropisation à l'Holocène en Provence et en Languedoc oriental, par les mollusques terrestres, Thèse de Doctorat, Paris, Université Paris I PanthéonSorbonne.

Milhaud, G., Nezit, J., 1991. Développement des molaires chez le mouton, étude morphologique, radiographique et microdurométrique, Recueil de Médecine Vétérinaire, 167, 121-127. 
Passey, B. H., Cerling, T. E., 2002. Tooth enamel mineralization in ungulates: Implications for recovering a primary isotopic time-series, Geochimica et Cosmochimica Acta, 66, 3225-3234.

Payne, S., 1985. Morphological distinctions between the mandibular teeth of young sheep, Ovis, and goats, Capra, Journal of Archaeological Science, 12, 139-147.

Pfeffer, P., 1967. Le mouflon de Corse (Ovis ammon musimon, Schreber 1972), position systématique, écologie et éthologie comparée, Mammalia, suppl. au nº 31.

Quittet, E., 1976. Les races ovines françaises, collection: les races d'animaux domestiques, $2^{\text {ème }}$ édition, La Maison rustique, Paris.

Sharp, Z. D., Cerling, T. E., 1998. Fossil isotope records of seasonal climate and ecology: Straight from the horse's month, Geology, 26, 219-222.

Suga, S., 1982. Progressive mineralization pattern of developing enamel during the maturation stage. Journal of Dental Research, 61, 1532-1542.

Toussaint, G., 2001. L'élevage des moutons, Edition de Vecchi, Paris.

Thiéry, J.C., Chemineau P., Hernandez X., Migaud, M., Malpaux, B., 2002. Neuroendocrinal interactions and seasonality. Domestic Animal Endocrinology, 23, 87-100.

Weinreb, M. M., Sharav, Y., 1964. Tooth development in sheep, American Journal of Veterinary Research, 25, 107, 891-908.

Zazzo, A., Balasse, M., Passey, B. H., Moloney, A. P., Monahan, F. J., Schmidt, O., 2010. The isotope record of short- and long-term dietary changes in sheep tooth enamel: Implications for quantitative reconstruction of paleodiets, Geochimica et Cosmochimica Acta, 74, 3571-3586. 
Table 1: Results from the stable oxygen isotope analysis $\left(\delta^{18} \mathrm{O}\right)$ of tooth enamel bioapatite from the modern sheep born in different periods of the year: Number of sample $(\mathrm{N})$, minimum $(\mathrm{min})$ and maximum (max) values for each tooth, mean and amplitude of intra-tooth variation (4). Sample position is expressed as the distance from the crown enamel root junction (ERJ), in millimeters (mm).

\begin{tabular}{|c|c|c|c|c|c|c|c|c|c|c|c|c|c|c|c|}
\hline \multirow{3}{*}{$\begin{array}{c}\text { Modern } \\
\text { specimens }\end{array}$} & \multirow{3}{*}{ Date of birth } & \multicolumn{14}{|c|}{$\delta^{18} \mathrm{O}_{\mathrm{VPB}}(\%)$ of enamel bioapatite } \\
\hline & & \multicolumn{7}{|c|}{ Second lower molar (M2) } & \multicolumn{7}{|c|}{$\begin{array}{r}\text { Third lower molar (M3) } \\
\end{array}$} \\
\hline & & $\mathrm{N}$ & $\min$ & $\begin{array}{l}\text { dist. from } \\
\text { ERJ }(\mathrm{mm})\end{array}$ & $\max$ & $\begin{array}{l}\text { dist. from } \\
\text { ERJ (mm) }\end{array}$ & $\Delta$ & mean & $\mathrm{N}$ & $\min$ & $\begin{array}{l}\text { dist. from } \\
\text { ERJ }(\mathrm{mm})\end{array}$ & $\max$ & $\begin{array}{l}\text { dist. from } \\
\text { ERJ (mm) }\end{array}$ & $\Delta$ & mean \\
\hline Ovis 1216 & February 8, 2001 & 15 & -6.2 & 18.6 & -1.7 & 6.6 & 4.5 & -4.5 & 22 & -5.2 & 17.8 & -1.1 & 30.7 & 4.1 & -2.8 \\
\hline Ovis 0026 & January 28, 2000 & 12 & -6.6 & 18.4 & -0.5 & 4.2 & 6.1 & -3.8 & 16 & -5.0 & 7.8 & -0.5 & 23.0 & 4.5 & -2.8 \\
\hline Ovis 8143 & February 3, 1998 & & & & & & & & 8 & -5.5 & 14.2 & -1.8 & 4.1 & 3.7 & -4.2 \\
\hline Ovis 9726 & April 29, 1999 & & & & & & & & 16 & -4.7 & 5.5 & -1.2 & 24.2 & 3.5 & -2.6 \\
\hline Ovis 9470 & September 5, 1999 & 9 & -5.6 & 9.9 & -0.6 & 2.2 & 5.1 & -3.4 & 13 & -5.4 & 3.4 & -0.2 & 17.9 & 5.2 & -2.3 \\
\hline Ovis 1511 & September 12, 2001 & 18 & -6.9 & 1.8 & -0.6 & 16.2 & 6.3 & -2.7 & 20 & -7.2 & 24.8 & -2.1 & 12.5 & 5.1 & -5.1 \\
\hline Ovis 0522 & September 18,2000 & 13 & -5.7 & 10.0 & -1.8 & 22.2 & 3.9 & -3.5 & 21 & -7.0 & 7.3 & -1.6 & 21.8 & 5.4 & -3.6 \\
\hline Ovis 0562 & September 20, 2000 & 12 & -5.1 & 6.8 & -1.1 & 20.7 & 4.0 & -3.3 & 19 & -6.8 & 3.9 & -1.8 & 18.1 & 5.0 & -3.6 \\
\hline
\end{tabular}


Table 2: Results from the stable oxygen isotope analysis $\left(\delta^{18} \mathrm{O}\right)$ of tooth enamel bioapatite from the sheep and goats from Collet-Redon: Number of sample (N), minimum (min) and maximum (max) values for each tooth, mean and amplitude of intra-tooth variation $(\Delta)$.

\begin{tabular}{|l|ccccc|}
\hline \multirow{2}{*}{ Specimen } & \multicolumn{5}{|c}{$\delta^{18} \mathrm{O}_{\mathrm{VPDB}}(\%$ o } \\
& $\mathrm{N}$ & $\mathrm{min}$ & $\mathrm{max}$ & $\Delta$ & mean \\
\hline Ovis MCR 3D M2 & 17 & -2.1 & 1.5 & 3.6 & -0.7 \\
Ovis MCR US182 M2 & 8 & -0.8 & 1.3 & 2.1 & 0.5 \\
Ovis MCR 3B M2 & 14 & -0.9 & 1.7 & 2.6 & 0.3 \\
Ovis MCR 3C M2 & 14 & -1.8 & 0.4 & 2.2 & -0.8 \\
Capra MCR 3D M2 & 15 & -1.6 & 1.3 & 2.9 & -0.01 \\
Capra MCR US186 M2 & 14 & -0.7 & 1.8 & 2.5 & 0.9 \\
\hline
\end{tabular}


Figure 1: Map of the study area with location of the archaeological sites mentioned in the text (circles) and the modern farm (square).

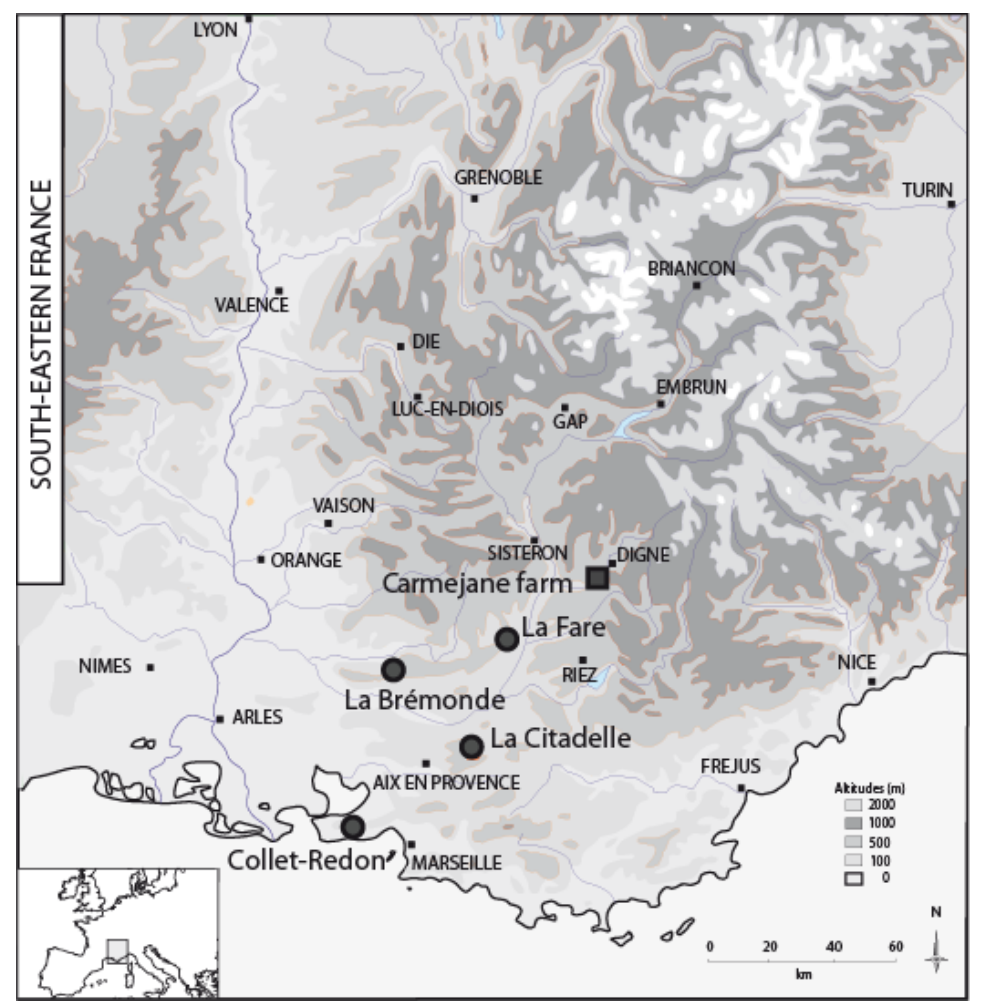


Figure 2: Variation in oxygen isotope ratios $\left(\delta^{18} \mathrm{O}\right)$ measured along the tooth crown of the second molars of modern sheep.

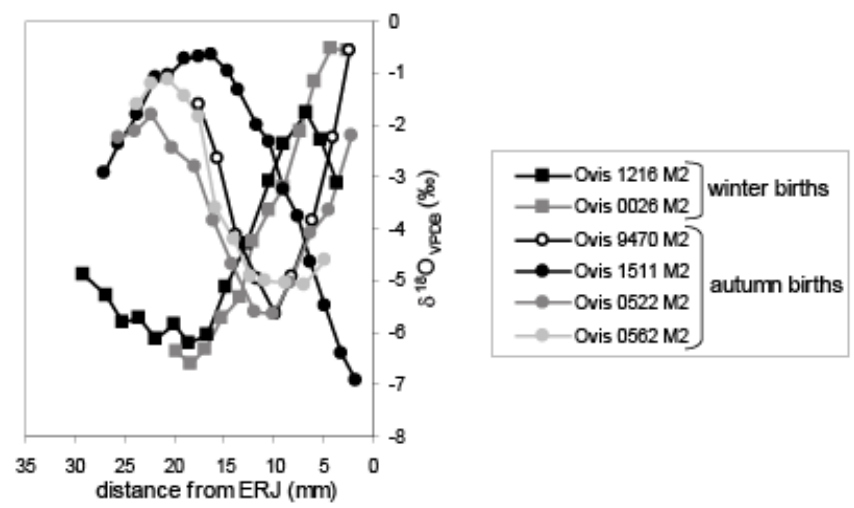


Figure 3: Variation in oxygen isotope ratios $\left(\delta^{18} \mathrm{O}\right)$ measured along the tooth crown of the third molars of modern sheep. (a) - all individuals; (b) - winter and spring births; (c) - autumn births.

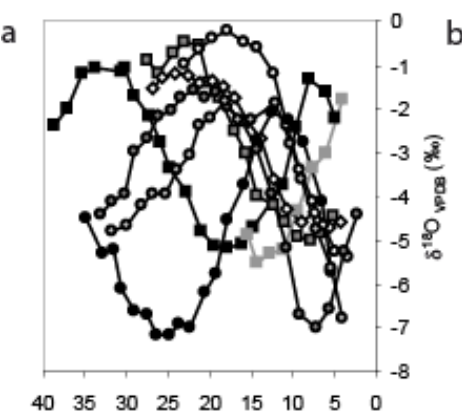

distance from ERJ $(\mathrm{mm})$
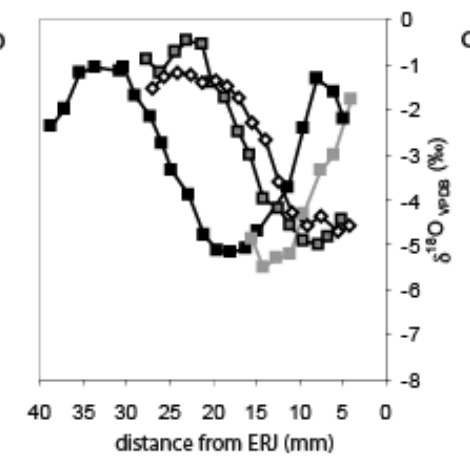

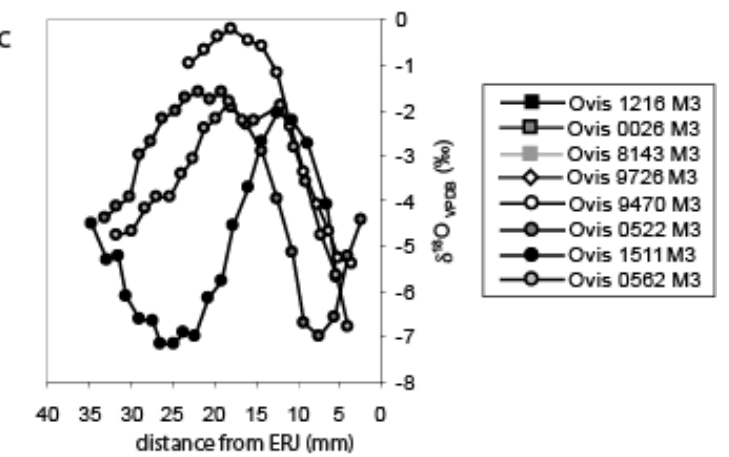


Figure 4: Variation in oxygen isotope ratios $\left(\delta^{18} \mathrm{O}\right)$ measured along the tooth crown of the second molars of archaeological sheep (Ovis aries) and goats (Capra hircus) collected from the site of ColletRedon (Martigues, Bouches-du-Rhône, France). (a) - all individuals; (b) - sheep; (c) - goats.

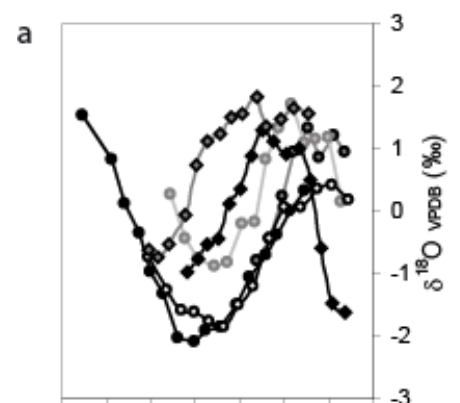

$\begin{array}{llllllll}35 & 30 & 25 & 20 & 15 & 10 & 5 & 0\end{array}$

distance from $E R(\mathrm{~mm})$

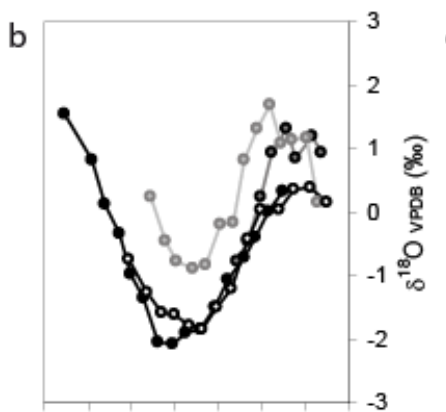

$\begin{array}{llllllll}35 & 30 & 25 & 20 & 15 & 10 & 5 & 0\end{array}$

distance from ERJ ( $\mathrm{mm}$ )

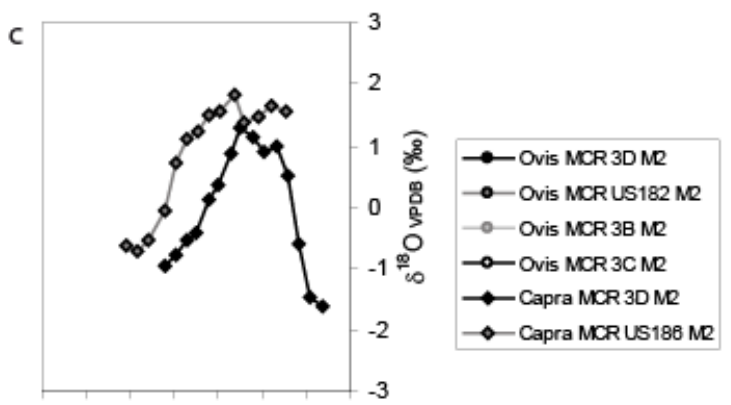

$\begin{array}{llllllll}35 & 30 & 25 & 20 & 15 & 10 & 5 & 0\end{array}$

distance from ERJ (mm) 
Figure 5: Comparison between results from the stable oxygen isotope analysis $\left(\delta^{18} \mathrm{O}\right)$ of the modern sheep and archaeological caprines teeth. (a) - comparison with modern sheep born in winter and sheep of Collet-Redon; (b) - comparison with modern sheep born in late summer to early autumn and sheep of Collet-Redon; (c) - comparison with modern sheep born in winter and goats of Collet-Redon; (d) comparison with modern sheep born in late summer to early autumn and goats of Collet-Redon.

a

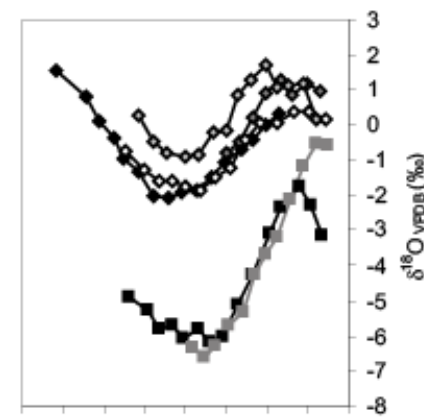

$\begin{array}{lllllllll}40 & 35 & 30 & 25 & 20 & 15 & 10 & 5 & 0\end{array}$ Normalized distance from ERJ ( $\mathrm{mm}$ )

C

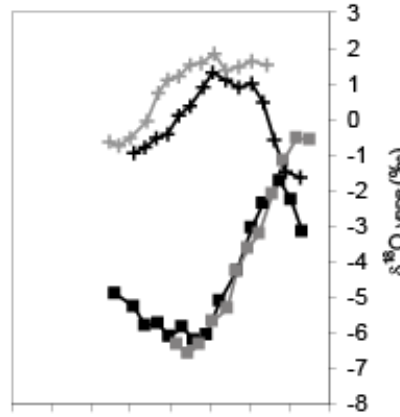

$\begin{array}{lllllllll}40 & 35 & 30 & 25 & 20 & 15 & 10 & 5 & 0\end{array}$ Normalized distance from ERJ $(\mathrm{mm})$ b

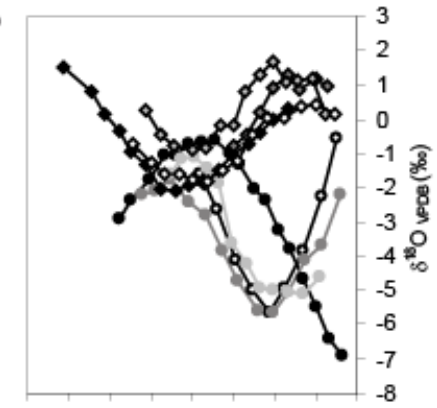

$\begin{array}{lllllllll}40 & 35 & 30 & 25 & 20 & 15 & 10 & 5 & 0\end{array}$

Normalized distance from ERJ $(\mathrm{mm})$

d

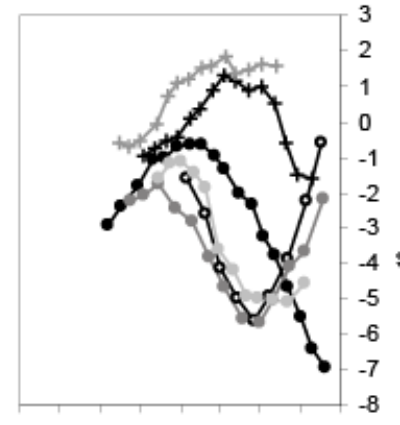

$\begin{array}{lllllllll}40 & 35 & 30 & 25 & 20 & 15 & 10 & 5 & 0\end{array}$

Normalized distance from ERJ (mm) 
Figure 6: Birth season, distribution of slaughtering and hypothesis of period site occupation and availability of milk.
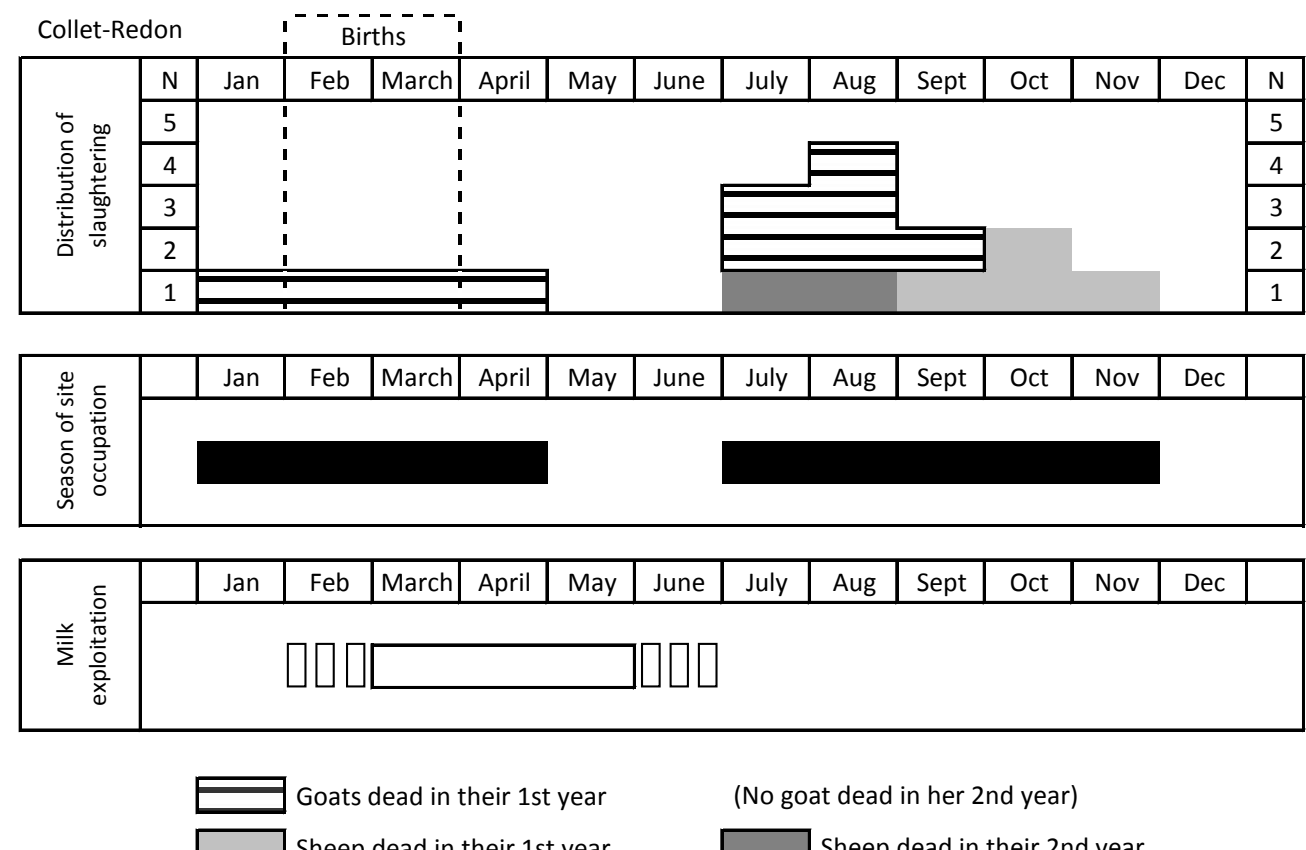

(No goat dead in her 2nd year)

Sheep dead in their 2nd year 
Appendix 1: Stable oxygen $\left(\delta^{18} \mathrm{O}\right.$ pDB $)$ isotope values of tooth enamel bioapatite of modern and archaeological domestic caprines. Sample position is the distance from the crown enamel root junction (ERJ), in millimeters (mm).

\begin{tabular}{|c|c|c|c|c|c|c|c|c|c|c|c|}
\hline \multicolumn{8}{|c|}{ Modern specimens second and third molar } & \multicolumn{4}{|c|}{ Archaeological specimens second molar } \\
\hline \multicolumn{2}{|c|}{ Ovis $1216 \mathrm{M} 2$} & \multicolumn{2}{|c|}{ Ovis $1511 \mathrm{M} 2$} & \multicolumn{2}{|c|}{ Ovis $0026 \mathrm{M} 3$} & \multicolumn{2}{|c|}{ Ovis $1511 \mathrm{M} 3$} & \multicolumn{2}{|c|}{ Ovis MCR 3D M2 } & \multicolumn{2}{|c|}{ Ovis MCR 3C M2 } \\
\hline$\delta^{18} \mathrm{O}(\%)$ & $(\mathrm{mm})$ & $\delta^{18} \mathrm{O}(\%)$ & $(\mathrm{mm})$ & $\delta^{18} \mathrm{O}(\%)$ & $(\mathrm{mm})$ & $\delta^{18} \mathrm{O}(\%)$ & $(\mathrm{mm})$ & $\delta^{18} \mathrm{O}(\%)$ & $(\mathrm{mm})$ & $\delta^{18} \mathrm{O}(\%)$ & $(\mathrm{mm})$ \\
\hline$-4,9$ & 29,2 & $-2,9$ & 27,1 & $-0,9$ & 27,6 & $-4,5$ & 34,8 & 1,5 & 32,7 & $-0,7$ & 25,3 \\
\hline$-5,3$ & 26,8 & $-2,4$ & 25,7 & $-1,2$ & 26,1 & $-5,3$ & 32,9 & 0,02 & 31,1 & $-1,3$ & 23,1 \\
\hline$-5,8$ & 25,3 & $-1,8$ & 23,7 & $-0,7$ & 24,4 & $-5,2$ & 31,6 & 0,8 & 29,5 & $-1,6$ & 21,5 \\
\hline$-5,7$ & 23,5 & $-1,1$ & 21,8 & $-0,5$ & 23,0 & $-6,1$ & 30,5 & 0,1 & 28,0 & $-1,6$ & 20,0 \\
\hline$-6,1$ & 21,9 & $-1,0$ & 20,7 & $-0,5$ & 21,3 & $-6,6$ & 29,0 & $-0,3$ & 26,4 & $-1,8$ & 18,4 \\
\hline$-5,8$ & 20,1 & $-0,7$ & 19,1 & $-1,4$ & 20,2 & $-6,7$ & 27,4 & $-1,0$ & 25,1 & $-1,8$ & 16,9 \\
\hline$-6,2$ & 18,6 & $-0,7$ & 17,6 & $-1,7$ & 18,7 & $-7,2$ & 26,4 & $-1,3$ & 23,6 & $-1,5$ & 15,2 \\
\hline$-6,0$ & 16,7 & $-0,6$ & 16,2 & $-2,5$ & 17,0 & $-7,2$ & 24,8 & $-2,0$ & 21,9 & $-1,2$ & 13,4 \\
\hline$-5,1$ & 14,8 & $-1,0$ & 14,6 & $-3,0$ & 15,7 & $-6,9$ & 23,7 & $-2,1$ & 20,1 & $-0,4$ & 11,7 \\
\hline$-4,3$ & 12,7 & $-1,3$ & 13,5 & $-4,0$ & 14,3 & $-7,0$ & 22,2 & $-1,9$ & 18,8 & 0,1 & 10,0 \\
\hline$-3,1$ & 10,5 & $-2,0$ & 11,8 & $-4,2$ & 12,4 & $-6,2$ & 20,6 & $-1,8$ & 17,1 & 0,05 & 8,1 \\
\hline$-2,4$ & 8,9 & $-2,3$ & 10,3 & $-4,6$ & 11,1 & $-5,8$ & 19,2 & $-1,5$ & 15,3 & 0,4 & 6,2 \\
\hline$-1,7$ & 6,6 & $-3,2$ & 9,0 & $-4,9$ & 9,5 & $-4,6$ & 17,8 & $-1,1$ & 13,9 & 0,4 & 4,5 \\
\hline$-2,3$ & 5,1 & $-3,8$ & 7,6 & $-5,0$ & 7,8 & $-3,7$ & 15,9 & $-0,7$ & 12,0 & 0,2 & 2,6 \\
\hline$-3,1$ & 3,6 & $-4,6$ & 6,2 & $-4,8$ & 6,7 & $-2,7$ & 14,2 & $-0,4$ & 10,8 & \multicolumn{2}{|c|}{ Capra MCR 3D M2 } \\
\hline \multicolumn{2}{|c|}{ Ovis 0026 M2 } & $-5,5$ & 4,7 & $-4,4$ & 5,1 & $-2,1$ & 12,5 & 0,001 & 9,3 & $\delta^{18} \mathrm{O}(\% \circ)$ & $(\mathrm{mm})$ \\
\hline$\delta^{18} \mathrm{O}(\%)$ & $(\mathrm{mm})$ & $-6,4$ & 3,2 & Ovis 81 & $\mathrm{M} 3$ & $-2,2$ & 10,6 & 0,3 & 7,7 & $-1,0$ & 21,0 \\
\hline$-6,3$ & 19,8 & $-6,9$ & 1,8 & $\delta^{18} \mathrm{O}(\% \circ)$ & $(\mathrm{mm})$ & $-2,7$ & 8,7 & Ovis MCR & $182 \mathrm{M} 2$ & $-0,8$ & 19,7 \\
\hline$-6,6$ & 18,4 & Ovis 94 & $\mathrm{M} 2$ & $-4,9$ & 15,5 & $-4,1$ & 6,5 & $\delta^{18} \mathrm{O}(\%)$ & $(\mathrm{mm})$ & $-0,5$ & 18,6 \\
\hline$-6,3$ & 16,9 & $\delta^{18} \mathrm{O}(\%)$ & $(\mathrm{mm})$ & $-5,5$ & 14,2 & $-5,7$ & 5,3 & $-0,8$ & 13,0 & $-0,4$ & 17,5 \\
\hline$-5,7$ & 15,3 & $-1,600$ & 17,5 & $-5,3$ & 12,7 & Ovis 05 & $\mathrm{M} 3$ & $-0,5$ & 11,7 & 0,1 & 16,1 \\
\hline$-5,3$ & 13,2 & $-2,623$ & 15,6 & $-5,2$ & 11,1 & $\delta^{18} \mathrm{O}(\% \circ)$ & $(\mathrm{mm})$ & 0,2 & 10,2 & 0,4 & 14,9 \\
\hline$-4,3$ & 12,0 & $-4,131$ & 13,7 & $-4,3$ & 9,4 & $-4,4$ & 33,0 & 0,9 & 8,8 & 0,9 & 13,6 \\
\hline$-3,7$ & 10,5 & $-4,968$ & 11,8 & $-3,3$ & 7,6 & $-4,1$ & 31,7 & 1,3 & 7,3 & 1,3 & 12,4 \\
\hline$-3,2$ & 9,0 & $-5,641$ & 9,9 & $-3,0$ & 6,0 & $-3,9$ & 30,1 & 0,9 & 6,0 & 1,1 & 11,1 \\
\hline$-2,1$ & 7,3 & $-4,932$ & 8,1 & $-1,8$ & 4,1 & $-3,0$ & 29,0 & 1,2 & 4,3 & 0,9 & 9,8 \\
\hline$-1,2$ & 5,8 & $-3,850$ & 6,0 & Ovis 97 & M3 & $-2,7$ & 27,5 & 0,9 & 3,1 & 1,0 & 8,3 \\
\hline$-0,5$ & 4,2 & $-2,247$ & 3,9 & $\delta^{18} \mathrm{O}(\%)$ & $(\mathrm{mm})$ & $-2,2$ & 26,2 & Ovis MCF & B M2 & 0,5 & 7,1 \\
\hline$-0,6$ & 2,6 & $-0,571$ & 2,2 & $-1,5$ & 26,9 & $-2,0$ & 24,6 & $\delta^{18} \mathrm{O}(\%)$ & $(\mathrm{mm})$ & $-0,6$ & 5,8 \\
\hline Ovis 05 & $\mathrm{M} 2$ & Ovis 1 & $\mathrm{M} 3$ & $-1,3$ & 25,7 & $-1,7$ & 23,4 & 0,3 & 22,8 & $-1,5$ & 4,6 \\
\hline$\delta^{18} \mathrm{O}(\%)$ & $(\mathrm{mm})$ & $\delta^{18} \mathrm{O}(\%)$ & $(\mathrm{mm})$ & $-1,2$ & 24,2 & $-1,6$ & 21,8 & $-0,5$ & 21,2 & $-1,6$ & 3,1 \\
\hline$-2,2$ & 25,7 & $-2,4$ & 38,8 & $-1,2$ & 22,5 & $-1,8$ & 20,5 & $-0,8$ & 19,7 & Capra MCR & $186 \mathrm{M} 2-1$ \\
\hline$-2,1$ & 24,0 & $-2,0$ & 37,2 & $-1,4$ & 21,2 & $-1,6$ & 19,2 & $-0,9$ & 17,9 & $\delta^{18} \mathrm{O}(\%)$ & $(\mathrm{mm})$ \\
\hline$-1,8$ & 22,2 & $-1,2$ & 35,3 & $-1,4$ & 19,6 & $-1,9$ & 18,0 & $-0,8$ & 16,4 & $-0,6$ & 25,3 \\
\hline$-2,4$ & 20,2 & $-1,1$ & 33,7 & $-1,5$ & 18,3 & $-2,3$ & 16,2 & $-0,2$ & 14,8 & $-0,7$ & 24,2 \\
\hline$-2,8$ & 18,0 & $-1,2$ & 30,7 & $-1,7$ & 17,1 & $-2,9$ & 14,3 & $-0,2$ & 13,4 & $-0,5$ & 23,0 \\
\hline$-3,8$ & 16,1 & $-1,1$ & 30,3 & $-2,3$ & 15,5 & $-4,0$ & 12,5 & 0,8 & 12,1 & $-0,1$ & 21,1 \\
\hline$-4,7$ & 14,2 & $-1,7$ & 29,0 & $-2,7$ & 13,9 & $-5,2$ & 10,7 & 1,3 & 10,6 & 0,7 & 19,8 \\
\hline$-5,6$ & 11,9 & $-2,1$ & 27,2 & $-3,6$ & 12,4 & $-6,7$ & 9,1 & 1,7 & 9,1 & 1,1 & 18,6 \\
\hline$-5,7$ & 10,0 & $-2,8$ & 25,9 & $-4,3$ & 10,7 & $-7,0$ & 7,3 & 1,1 & 7,8 & 1,2 & 17,3 \\
\hline$-5,0$ & 8,3 & $-3,3$ & 24,7 & $-4,6$ & 9,0 & $-6,6$ & 5,6 & 1,2 & 6,5 & 1,5 & 16,0 \\
\hline$-4,1$ & 6,3 & $-3,9$ & 22,8 & $-4,4$ & 7,4 & $-5,2$ & 3,9 & 1,2 & 4,9 & 1,6 & 14,8 \\
\hline$-3,7$ & 4,3 & $-4,8$ & 21,0 & $-4,7$ & 5,5 & $-4,4$ & 2,3 & 0,1 & 3,5 & 1,8 & 13,1 \\
\hline$-2,2$ & 2,1 & $-5,1$ & 19,4 & $-4,6$ & 4,3 & Ovis 05 & $\mathrm{M} 3$ & & & 1,4 & 12,0 \\
\hline Ovis 05 & $\mathrm{M} 2$ & $-5,2$ & 17,8 & Ovis 94 & $\mathrm{M} 3$ & $\delta^{18} \mathrm{O}(\%)$ & $(\mathrm{mm})$ & & & 1,5 & 10,4 \\
\hline$\delta^{18} \mathrm{O}(\%)$ & $(\mathrm{mm})$ & $-5,1$ & 16,1 & $\delta^{18} \mathrm{O}(\%)$ & $(\mathrm{mm})$ & $-4,8$ & 31,7 & & & 1,6 & 9,0 \\
\hline$-1,6$ & 23,7 & $-4,7$ & 14,8 & $-1,0$ & 22,9 & $-4,7$ & 29,9 & & & 1,6 & 7,2 \\
\hline$-1,2$ & 22,4 & $-3,5$ & 12,8 & $-0,7$ & 21,2 & $-4,2$ & 28,3 & & & & \\
\hline$-1,1$ & 20,7 & $-3,7$ & 11,3 & $-0,4$ & 19,6 & $-3,9$ & 26,9 & & & & \\
\hline$-1,4$ & 19,1 & $-2,4$ & 9,6 & $-0,2$ & 17,9 & $-3,9$ & 25,4 & & & & \\
\hline$-1,9$ & 17,5 & $-1,3$ & 8,0 & $-0,5$ & 15,9 & $-3,4$ & 23,9 & & & & \\
\hline$-3,6$ & 15,9 & $-1,6$ & 6,0 & $-0,6$ & 14,3 & $-3,1$ & 22,4 & & & & \\
\hline$-4,2$ & 14,0 & $-2,2$ & 4,8 & $-1,2$ & 12,4 & $-2,4$ & 21,2 & & & & \\
\hline$-4,9$ & 12,3 & & & $-2,4$ & 10,7 & $-2,2$ & 19,8 & & & & \\
\hline$-5,0$ & 10,8 & & & $-3,4$ & 9,1 & $-1,8$ & 18,1 & & & & \\
\hline$-5,0$ & 8,8 & & & $-4,1$ & 7,5 & $-2,2$ & 16,6 & & & & \\
\hline$-5,1$ & 6,8 & & & $-4,7$ & 6,2 & $-2,2$ & 15,1 & & & & \\
\hline$-4,6$ & 4,8 & & & $-5,3$ & 5,0 & $-3,6$ & 13,6 & & & & \\
\hline & & & & $-5,4$ & 3,4 & $-1,9$ & 12,0 & & & & \\
\hline & & & & & & $-2,8$ & 10,4 & & & & \\
\hline & & & & & & $-3,6$ & 8,9 & & & & \\
\hline & & & & & & $-4,7$ & 7,2 & & & & \\
\hline & & & & & & $-5,6$ & 5,4 & & & & \\
\hline & & & & & & $-6,8$ & 3,9 & & & & \\
\hline
\end{tabular}

